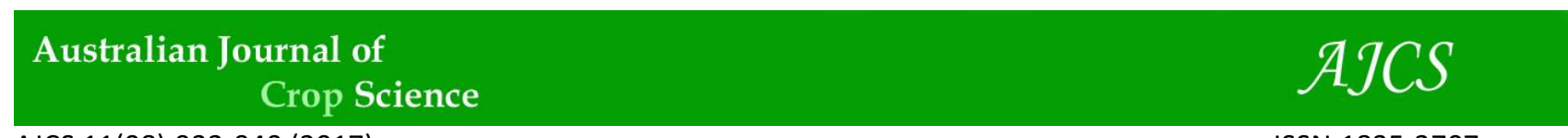

AJCS 11(08):932-940 (2017)

ISSN:1835-2707

doi: 10.21475/ajcs.17.11.08.pne339

\title{
Participatory assessment of potato farming systems, production constraints and cultivar preferences in Uganda
}

\author{
Prossy Namugga $^{* 1,2}$, Rob Melis ${ }^{1}$, Julia Sibiya $^{1}$, Alex Barekye ${ }^{2}$ \\ ${ }^{1}$ African Centre for Crop Improvement, University of KwaZulu-Natal, School of Agricultural, Earth and \\ Environmental Sciences, Private Bag X01, Scottsville 3209, Pietermaritzburg, South Africa \\ ${ }^{2}$ National Agricultural Research Organisation (NARO), Kachwekano Zonal Agricultural Research and \\ Development Institute, P.O. Box 421 Kabale, Uganda
}

*Corresponding author: namuggak@gmail.com

\begin{abstract}
Potato (Solanum tuberosum L.) is a major food and cash crop mainly grown by small-scale farmers in the highland regions of Uganda. Farmer practices and constraints in potato production and management differ from one area to another and so are desired attributes. A survey was conducted in eight major potato producing districts of Uganda. The study districts were from Central, Eastern and South Western regions of the country. The survey was carried out from May to August 2015. A semi-structured questionnaire was administered to 577 individual farmers. The results showed that potato is produced for both food and cash benefits in all the districts. Only $2 \%$ of the respondents from Eastern and South western Uganda obtained seed from research stations while all respondents from Central Uganda used farm saved seed. Major production challenges were pests and diseases. The major pests were aphids and cutworms while late blight and bacterial wilt were the prominent diseases. Across the three regions Rwangume and Victoria were the commonly grown cultivars while Cruza and Marierahinda were the most rejected varieties. These were rejected on account of being white skinned with low marketability and Cruza becomes marshy on cooking. High yield, resistance to late blight, early maturity and marketability were the most preferred attributes in new varieties. Late blight had been experienced by $98 \%$ of the farmers and $96 \%$ of these reported to have used fungicides to manage the disease.
\end{abstract}

Keywords: Attributes, variety, farmer practices, diseases, late blight, management.

\section{Introduction}

Potato (Solanum tuberosum L.) is a major food and cash crop, mainly grown by small-scale farmers in the highland regions of many African countries. Uganda is the ninth largest producer of potato in Africa with an annual production of 188,000 tons harvested from about 39000 ha per year (FAOSTAT, 2014). The major production areas are the highlands of south-western Uganda, comprising of Kabale, Kanungu and Kisoro districts which account for $60 \%$ of total national production. The other potato producing areas are Kapchorwa, Sironko, Bulambuli and Bududa districts on the slopes of Mt Elgon in Eastern Uganda and Nebbi district in north-western Uganda. Potato cultivation has spread to non-traditional producing areas in Central Uganda, especially Mubende, Rakai and Masaka districts.

Potato yields in Uganda have remained low about $4.8 \mathrm{t} \mathrm{ha}^{-1}$ (FAOSTAT, 2014) against a potential of about $25 \mathrm{t} \mathrm{ha}^{-1}$ which can be achieved under good management and when suitable varieties are deployed. These low yields have been attributed to a number of confounding factors which are biotic, abiotic, and socio-economic constraints as well as poorly adapted and adopted varieties. Diseases are the major limiting factor and these include; - late blight caused by Phytophthora infestans (Mont.) de Bary, bacterial wilt (BW) (Ralstonia solanacearum) (Muthoni et al., 2013) and viruses (Muhinyuza et al., 2012).
Late blight is the most devastating disease of potato leading to yield losses of up to $70 \%$ (Sedláková et al., 2011). The disease is present in all main potato growing areas (Hijmans, 2001). It is favoured by moderately low temperatures and extended times of leaf dampness. It is particularly detrimental in the highland tropics where potatoes are grown throughout the year, coupled with poor ability of farmers to understand and manage the disease (Garrett et al., 2001). Late blight regularly reduces potato productivity leading to large differences between actual and realised yields. Attempts to develop late blight resistant cultivars therefore call for superior attention to disease management.

Most of the available potato varieties in Uganda are late maturing with physiological maturity attainable after 100 days from planting if they are to reach the full yield potential of more than $15 \mathrm{t} \mathrm{ha}^{-1}$. These varieties were selected for the highlands (>2000 meters above seas level (masl)), and thus are well adapted and produce good yields with excellent culinary qualities in the highlands. Attempts to grow these varieties at low and mid-altitudes ( $<1700$ masl) have resulted into loss of tuber quality and low yields (Hassanpanah et al., 2008). Early maturing varieties would allow all year round cultivation of potato with favourable rotation periods and improved yields in the face of climate change. This is especially advantageous for smallholder farmers who depend entirely on potato for both food and income security in areas 
with land shortage. Additionally, these varieties would be grown in low altitude areas of Uganda with short lived rainfall seasons where potato production is currently expanding. . Short rainy seasons are often erratic; early maturing cultivars stand a higher chance of carrying the crop to full maturity. The National Agricultural Research Organisation (NARO) in collaboration with the International Potato Center (CIP) has released many potato varieties. Some of these varieties have not been adopted by farmers. Farmers prefer their own varieties that they have kept for a long time because of some special attributes (Witcombe, 2009).liIt was reported that participatory variety selection (PVS) may improve the adoption of varieties and boost productivity (Joshi and Witcombe, 1996). To accelerate variety adoption, farmer preferred qualities must be considered in the process of cultivar development. In participatory plant breeding (PPB), the preferences of the end-users and production environments are identified through participatory rural appraisal (PRA) (Witcombe et al., 2005). It is against this background therefore, that a participatory rural appraisal was carried out to identify key potato production constraints, varieties grown, and farmers' knowledge of potato diseases. The diseitent in all main potatogrowing areas (Hijmans et al., 2001).

\section{Results}

\section{Household and farm characteristics}

A total of 577 farmers were interviewed from three major potato growing regions in eight districts, 31 sub-counties and 165 villages. Sixty percent of the interviewed farmers were from South Western Uganda. An equal number of males and females were surveyed in Kanungu (50\%), more females in Kabale, Kisoro, Kween and Kapchorwa, while more males (were surveyed in Central Uganda. The farms are located between 1256 and 2480 masl. . Most of the respondents (30\% and above) had their age between 21 and 55 years in all the surveyed districts. Rakai district had more young people (6\%) involved in potato growing while Kisoro had $23 \%$ of the people aged above 55 years (Table 1).

\section{Potato farming system in Uganda}

Five commonly grow crops were mentioned in order of importance in the study districts. In all the districts, farmers ranked potato as their number one crop followed by either beans or maize. Sorghum, peas and sweet potatoes were typically grown in the Kigezi region; banana and coffee in Rakai, Lwengo and Mbale, while barley and wheat were common in Kween and Kapchorwa (Table 2). These crops are planted on small-scale farms for food and income as well as to guard against the risk of crop failure and for rotational purposes.

The most common source of planting materials used in the three regions and the respective districts was farm saved seed. This is either from the previous harvest or other farmers. More seed was obtained from the market and local traders in Eastern Uganda while in Central Uganda there was exclusive use of farm saved seed. To some extent farmers used seed from research stations, with more farmers in South Western Uganda (Table 3).

Rwangume was number one potato variety followed by Victoria in all the districts. However, in Kisoro Kinigi was preferred to Rwangume. Rwashaki and Rutuku were generally found in the South Western region, with Sutama typically in Kisoro; Kabera and Kasumali in the Central region. Kachpot 1 and Wanale were found in Eastern Uganda (Table 4). Farmers also tended to give varieties names of the person and places where they were obtained. For example, the potato variety Rwangume was called by different names in the three regions: Deodeo in in the Central and Kabale and or Rwangyema in Eastern Uganda. The naming is assumed to be the farmer or area where the seed was obtained. However, some farmers were not aware of the varieties they were growing.

Farmers in each district mentioned potato cultivars abandoned over the past ten years. Cruza was most dropped in South Western Uganda and Mbale district compared to other varieties. Mbubamagara, Rutuku, Marierahinda, and Kimuri were dropped in South Western Uganda while Kabale, Marierahinda, Kabera, Singo and Kawanda were abandoned in the Central region. In addition, Cruza, and Meru were largely rejected in Eastern Uganda. Farmers gave a range of reasons as to why they abandoned these varieties. Reduced yields was common across all the regions. This was followed by reduced market, susceptibility to blight and introduction of new and high yielding varieties (Table 5). Long maturity period was a typically cited in Eastern Uganda. General susceptibility to pests and diseases, and unavailability of seed were also mentioned.

\section{Potato production constraints}

In general, diseases were the main constraint limiting potato production across all the regions. Other challenges were pests, high cost of agro inputs, limited land for potato production, reducing yields and unfavourable weather conditions (Table 6). Major diseases were bacterial wilt in the low lands and late blight in the highland areas. Cutworms and aphids were the most predominant pests across all the regions. The potato tuber moth was mainly cited in the highland regions while leaf miner was mentioned in the districts of Kabale, Kisoro and Kanungu.

\section{Farmers' knowledge of late blight and management of the disease}

Most of the respondents had experienced late blight (LB) on their farms. It is a common disease devastating potato both in the high lands and low lands. Farmers have to spend a lot of money in controlling LB which increases the costs of production. Farmers recognize LB in different ways; spotted and burnt like leaves, leaves dry out and in severe cases both leaves and stems rot (Table 7). On the other hand, some farmers had no idea of the symptoms while others confused nutrient deficiency and maturity with late blight. Over 50\% of the respondents in the districts of Kabale, Kisoro and Kanungu, mentioned season B (October-December) when $\mathrm{LB}$ is more severe while in Central Uganda farmers experienced late blight severely during both seasons. In Eastern Uganda the disease was found to be more severe in season $\mathrm{A}$ and heavy rains was the main enhancing condition in all the districts (Table 7). Most of the respondents did not know how late blight is spread. On the main methods of spread, air or wind and rain were cited by most of the respondents. Over $90 \%$ of the respondents used fungicides to manage late blight on their farms. About $50 \%$ of the respondents entirely used contact fungicides while the remainder either used systemic or contact and systemic fungicides together (Table 8). Whereas some farmers could tell the name of the fungicide used or show the label, others, especially in Rakai (14\%), did not know the fungicide being 
Table 1. Description of household characteristics in surveyed districts of Uganda in the year 2015

\begin{tabular}{|c|c|c|c|c|c|c|c|c|c|}
\hline \multirow[b]{2}{*}{ Variable } & \multicolumn{6}{|c|}{ District } & \multirow[b]{2}{*}{ Kisoro } & \multirow[b]{2}{*}{ Kanungu } & \multirow[b]{4}{*}{ Total $/ 577$} \\
\hline & Lwengo & Rakai & Kapchorwa & Kween & Mbale & Kabale & & & \\
\hline Altitude (masl) & 1338 & 1256 & 2061 & 2442 & 1709 & 2480 & 2106 & 1959 & \\
\hline Number of farmers interviewed & 68 & 63 & 42 & 30 & 28 & 164 & 112 & 70 & \\
\hline \multicolumn{10}{|l|}{ Gender } \\
\hline$\%$ Males & 62 & 54 & 48 & 47 & 71 & 47 & 48 & 50 & \\
\hline$\%$ Females & 38 & 46 & 52 & 53 & 29 & 53 & 52 & 50 & \\
\hline \multicolumn{10}{|l|}{ Age of respondents $(\%)$} \\
\hline Less than 21 & 0 & 6 & 0 & 0 & 0 & 3 & 2 & 0 & \\
\hline Between 21-35 & 37 & 46 & 38 & 57 & 32 & 42 & 38 & 49 & \\
\hline Between 36-55 & 50 & 37 & 50 & 30 & 61 & 37 & 38 & 37 & \\
\hline More than 55 & 13 & 11 & 12 & 13 & 7 & 18 & 23 & 14 & \\
\hline Size of family land under potato (ha) & 2.0 & 1.0 & 3.1 & 1.6 & 0.9 & 0.7 & 1.1 & 0.9 & \\
\hline Average years of potato production & 6.1 & 9.7 & 10.4 & 13.5 & 11.3 & 14.1 & 14.0 & 11.1 & \\
\hline
\end{tabular}

Table 2. Five commonly grown crops in each district as mentioned by farmers.

\begin{tabular}{|c|c|c|c|c|c|}
\hline \multirow[b]{2}{*}{ District } & \multicolumn{5}{|c|}{ Crop in order of importance } \\
\hline & & & & & \\
\hline Kabale & Potato & Beans & Sorghum & Sweet potato & Peas \\
\hline Kisoro & Potato & Beans & Maize & Sorghum & Sweet potato \\
\hline Kanungu & Potato & Beans & Sorghum & Sweet potato & Maize \\
\hline Rakai & Potato & Beans & Maize & Banana & Coffee \\
\hline Lwengo & Potato & Maize & Beans & Banana & Coffee \\
\hline Kween & Potato & Maize & Barley & Cabbage & Wheat \\
\hline Kapchorwa & Potato & Maize & Onions & Wheat & Beans \\
\hline Mbale & Potato & Beans & Onions & Banana & Coffee \\
\hline
\end{tabular}

Table 3. Seed source in the three potato growing regions ( $\%$ of respondents).

\begin{tabular}{|c|c|c|c|c|c|}
\hline & & & Seed source & & \\
\hline Region & Farm saved & Other farmers & Research station & Market & Local traders \\
\hline Central & 69.7 & 53.4 & 0.0 & 0.8 & 0.0 \\
\hline Eastern & 43.0 & 44.0 & 3.0 & 27.0 & 10.0 \\
\hline South Western & 69.9 & 27.8 & 15.9 & 18.2 & 14.7 \\
\hline Mean & 60.9 & 41.7 & 6.3 & 15.3 & 8.2 \\
\hline
\end{tabular}


Table 4. Commonly grown potato varieties across the surveyed districts (\% of respondents).

\begin{tabular}{|c|c|c|c|c|c|c|c|c|}
\hline \multirow[b]{2}{*}{ Cultivar } & \multicolumn{5}{|c|}{ District } & \multirow[b]{2}{*}{ Kween } & \multirow[b]{2}{*}{ Kapchorwa } & \multirow[b]{2}{*}{ Mbale } \\
\hline & Kabale & Kisoro & Kanungu & Rakai & Lwengo & & & \\
\hline Rwangume & 93.3 & 25.0 & 98.0 & 98.4 & 95.6 & 33.3 & 14.3 & 82.1 \\
\hline Victoria & 25.0 & 6.3 & 12.9 & 14.3 & 2.9 & 31.3 & 14.8 & 50.0 \\
\hline Kinigi & 29.9 & 87.5 & 34.3 & 0.0 & 0.0 & 0.0 & 0.0 & 0.0 \\
\hline Rutuku & 1.8 & 0.0 & 5.7 & 0.0 & 0.0 & 0.0 & 0.0 & 0.0 \\
\hline Rwashaki & 9.2 & 16.1 & 1.4 & 0.0 & 0.0 & 0.0 & 0.0 & 0.0 \\
\hline Wanale & 0.0 & 0.0 & 0.0 & 0.0 & 0.0 & 13.3 & 2.4 & 7.1 \\
\hline Kasumali & 0.0 & 0.0 & 0.0 & 7.9 & 0.0 & 0.0 & 0.0 & 0.0 \\
\hline Sutama & 0.0 & 16.1 & 0.0 & 0.0 & 0.0 & 0.0 & 0.0 & 0.0 \\
\hline
\end{tabular}

Table 5. Abandoned potato cultivars and reasons for abandonment over the past ten years ( $\%$ of respondent farmers) in the surveyed districts.

\begin{tabular}{|c|c|c|c|c|c|c|c|c|}
\hline \multirow[b]{2}{*}{ Abandoned varieties } & \multicolumn{8}{|c|}{ District } \\
\hline & Kabale & Kisoro & Kanungu & Rakai & Lwengo & Kween & Kapchorwa & Mbale \\
\hline Cruza & 37.2 & 33.9 & 54.3 & 0.0 & 0.0 & 6.7 & 7.1 & 32.1 \\
\hline Bumbamagara & 29.3 & 0.0 & 10.0 & 0.0 & 0.0 & 0.0 & 0.0 & 0.0 \\
\hline Kimuri & 22.6 & 0.0 & 47.1 & 0.0 & 0.0 & 0.0 & 0.0 & 0.0 \\
\hline Rutuku & 21.3 & 13.4 & 7.1 & 0.0 & 0.0 & 0.0 & 0.0 & 0.0 \\
\hline Singo & 0.0 & 0.0 & 0.0 & 23.8 & 36.9 & 0.0 & 0.0 & 0.0 \\
\hline Sutama & 0.0 & 32.1 & 0.0 & 0.0 & 0.0 & 0.0 & 0.0 & 0.0 \\
\hline Sangema & 0.0 & 27.7 & 0.0 & 0.0 & 0.0 & 0.0 & 4.8 & 17.9 \\
\hline Marierahinda & 13.4 & 4.5 & 0.0 & 34.9 & 15.4 & 0.0 & 0.0 & 0.0 \\
\hline Kabale & 0.0 & 0.0 & 0.0 & 50.8 & 1.5 & 3.3 & 0.0 & 7.1 \\
\hline Kabera & 0.0 & 0.0 & 0.0 & 7.9 & 50.8 & 0.0 & 0.0 & 0.0 \\
\hline Meru & 0.0 & 0.0 & 0.0 & 0.0 & 0.0 & 40.0 & 7.1 & 0.0 \\
\hline \multicolumn{9}{|l|}{ Reason for rejection } \\
\hline Reduced or no market & 30.1 & 30.0 & 17.6 & 18.3 & 17.6 & 17.3 & 17.4 & 9.8 \\
\hline Susceptible to blight & 7.7 & 0.0 & 0.0 & 8.7 & 15.5 & 4.6 & 0.0 & 0.0 \\
\hline Low/reduced yields & 36.3 & 43.8 & 29.4 & 36.9 & 34.2 & 40.0 & 28.1 & 25.6 \\
\hline New and high yielding varieties & 14.7 & 5.3 & 10.4 & 0.0 & 0.4 & 8.2 & 0.0 & 3.7 \\
\hline Long maturity period & 0.0 & 0.0 & 0.0 & 0.0 & 0.0 & 7.3 & 7.4 & 7.3 \\
\hline Un availability of seed & 0.0 & 8.2 & 8.2 & 0.0 & 0.0 & 0.0 & 9.1 & 19.5 \\
\hline Susceptible to pests and diseases & 3.5 & 2.4 & 6.5 & 0.0 & 0.0 & 0.0 & 5.0 & 0.0 \\
\hline
\end{tabular}

Susceptible to pests and diseases 
Table 6. Potato production constraints as cited by farmers (\% of respondents).

\begin{tabular}{|c|c|c|c|c|c|c|c|c|}
\hline \multirow[b]{2}{*}{ Constraint } & \multicolumn{8}{|c|}{ istrict } \\
\hline & Kabale & Kisoro & Kanungu & Rakai & Lwengo & Kween & Kapchorwa & Mbale \\
\hline Diseases & 42.5 & 54.9 & 24.6 & 34.0 & 19.5 & 42.9 & 38.9 & 38.6 \\
\hline Pests & 5.7 & 16.7 & 3.9 & 36.2 & 25.7 & 30.4 & 19.4 & 28.1 \\
\hline Limited capital to buy inputs & 0.0 & 0.0 & 4.8 & 2.8 & 3.5 & 0.0 & 0.0 & 0.0 \\
\hline Low yields & 6.9 & 3.1 & 11.1 & 0.0 & 0.0 & 1.8 & 1.4 & 0.0 \\
\hline High cost of agro-inputs & 2.0 & 3.1 & 0.0 & 7.1 & 9.7 & 3.6 & 0.0 & 3.5 \\
\hline Unfavourable weather conditions & 0.0 & 3.7 & 2.4 & 0.0 & 2.6 & 0.0 & 2.4 & 0.0 \\
\hline Limited land for potato production & 3.7 & 0.0 & 3.2 & 2.1 & 6.2 & 1.8 & 0.0 & 0.0 \\
\hline Low market prices at harvest & 0.0 & 0.0 & 0.0 & 7.1 & 4.4 & 10.7 & 9.7 & 7.0 \\
\hline Declining soil fertility & 4.5 & 3.7 & 0.0 & 2.8 & 0.0 & 0.0 & 0.0 & 3.1 \\
\hline \multicolumn{9}{|l|}{ Major diseases } \\
\hline Bacterial wilt & 47.5 & 36.2 & 42.4 & 47.2 & 39.6 & 48.3 & 47.6 & 44.3 \\
\hline Late blight & 47.5 & 38.6 & 42.4 & 49.6 & 56.8 & 50.0 & 48.8 & 45.9 \\
\hline Viral diseases & 4.4 & 24.1 & 14.5 & 2.4 & 0.0 & 1.7 & 1.2 & 9.8 \\
\hline \multicolumn{9}{|l|}{ Major pests } \\
\hline Cutworms & 15.5 & 8.8 & 19.8 & 14.5 & 31.5 & 77.8 & 46.3 & 35.0 \\
\hline Aphids & 35.7 & 41.7 & 49.5 & 6.0 & 5.4 & 5.6 & 2.4 & 55.0 \\
\hline Leaf miners & 9.4 & 32.4 & 4.5 & 0.0 & 0.0 & 0.0 & 0.0 & 0.0 \\
\hline Potato tuber moth & 15.5 & 5.9 & 1.8 & 0.0 & 0.0 & 5.6 & 2.4 & 0.0 \\
\hline
\end{tabular}

Table 7. Farmers ability to recognize late blight (\% of respondents in each district).

\begin{tabular}{|c|c|c|c|c|c|c|c|c|}
\hline & \multicolumn{6}{|c|}{ District } & \multirow[b]{2}{*}{ Kapchorwa } & \multirow[b]{2}{*}{ Mbale } \\
\hline & Kabale & Kisoro & Kanungu & Rakai & Lwengo & Kween & & \\
\hline \multicolumn{9}{|l|}{ Symptoms } \\
\hline Burnt leaves & 20.7 & 22.3 & 14.3 & 39.7 & 23.5 & 40 & 59.5 & 60.7 \\
\hline Spotted leaves & 52.4 & 59.8 & 93.9 & 55.6 & 58.8 & 43.3 & 23.8 & 35.7 \\
\hline Rotting of leaves and stems & 8.5 & 0.0 & 12.2 & 0.0 & 2.9 & 0.0 & 7.1 & 0.0 \\
\hline Leaves dry and rot & 25.6 & 27.7 & 12.2 & 0.0 & 1.5 & 0.0 & 14.3 & 0.0 \\
\hline Premature falling of leaves & 6.7 & 0.9 & 18.4 & 1.6 & 2.9 & 6.7 & 2.4 & 0.0 \\
\hline Yellowing of leaves and stem & 4.9 & 0.0 & 38.8 & 20.6 & 14.7 & 20.0 & 14.3 & 10.7 \\
\hline \multicolumn{9}{|l|}{ Season when late blight is severe } \\
\hline A & 1.2 & 17 & 5.7 & 42.9 & 17.7 & 76.7 & 90.5 & 85.7 \\
\hline B & 92.7 & 71.4 & 57.1 & 23.8 & 51.5 & 3.3 & 2.4 & 3.6 \\
\hline Both A and B & 5.5 & 10.7 & 37.1 & 25.4 & 19.1 & 16.7 & 2.4 & 7.1 \\
\hline \multicolumn{9}{|l|}{ Enhancing conditions } \\
\hline Heavy rains & 97.6 & 95.5 & 100 & 76.2 & 80.9 & 93.3 & 95.2 & 85.7 \\
\hline Not sure & 1.8 & 2.7 & 0.0 & 15.8 & 8.8 & 3.3 & 0.0 & 10.7 \\
\hline \multicolumn{9}{|l|}{ Method of spread } \\
\hline Rain & 9.1 & 0.9 & 0.0 & 1.6 & 14.7 & 13.3 & 9.5 & 7.1 \\
\hline None & 86 & 97.3 & 0.0 & 85.7 & 72.1 & 80 & 78.6 & 85.7 \\
\hline
\end{tabular}

*season A (short rains of March -May) and season B (long rains of August-December). 
Table 8. Management of late blight on the farm (\% of respondents in each district).

\begin{tabular}{|c|c|c|c|c|c|c|c|c|c|}
\hline \multirow[b]{3}{*}{ Control method } & \multirow{4}{*}{$\begin{array}{l}\text { Chemical control } \\
\text { None }\end{array}$} & \multicolumn{6}{|c|}{ District } & \multirow{3}{*}{ Kapchorwa } & \multirow[b]{2}{*}{ Mbale } \\
\hline & & Kabale & Kisoro & Kanungu & Rakai & Lwengo & Kween & & \\
\hline & & 93.9 & 98.2 & $98.6^{\circ}$ & 96.8 & $92.7^{\circ}$ & 96.7 & & 96.4 \\
\hline & & 6.1 & 1.8 & 1.4 & 3.2 & 7.4 & 3.3 & 4.8 & 3.6 \\
\hline \multirow{3}{*}{ Fungicides used } & Contact (Mancozeb) & 67.7 & 87.5 & 70.0 & 63.5 & 88.2 & 53.3 & 64.3 & 96.4 \\
\hline & Systemic (Agrolazyl) & 0.0 & 0.0 & 0.0 & 0.0 & 2.9 & 0.0 & 2.4 & 0.0 \\
\hline & Both contact and systemic & 26.2 & 9.8 & 27.1 & 11.1 & 1.5 & 33.3 & 23.8 & 0.0 \\
\hline \multirow[t]{2}{*}{ Source of fungicides } & Agro-input dealers & 76.2 & 98.2 & 57.1 & 96.8 & 92.7 & 96.7 & 95.2 & 78.6 \\
\hline & General traders & 17.7 & 0.0 & 41.4 & 0.0 & 0.0 & 0.0 & 0.0 & 17.9 \\
\hline \multirow{5}{*}{$\begin{array}{l}\text { Number of times of } \\
\text { spraying in a season }\end{array}$} & Once & 4.9 & 0.0 & 0.0 & 0.0 & 0.0 & 3.3 & 11.9 & 0.0 \\
\hline & Twice & 39.0 & 8.0 & 12.9 & 1.6 & 10.3 & 20.0 & 57.1 & 20.0 \\
\hline & Thrice & 28.7 & 35.7 & 58.6 & 28.6 & 27.9 & 50.0 & 31.0 & 40.0 \\
\hline & More than three times & 22.0 & 53.6 & 28.6 & 66.7 & 52.9 & 16.7 & 0.0 & 36.0 \\
\hline & None & 5.5 & 2.7 & 0.0 & 3.2 & 8.8 & 10.0 & 0.0 & 4.0 \\
\hline \multirow[t]{4}{*}{ Spray intervals } & Weekly & 25.0 & 25.9 & 14.3 & 16.4 & 16.9 & 30.0 & 28.6 & 39.3 \\
\hline & Biweekly & 34.8 & 50.9 & 50.0 & 47.5 & 33.9 & 43.3 & 57.1 & 25.0 \\
\hline & After 3 weeks & 34.2 & 21.4 & 34.3 & 14.8 & 29.2 & 3.3 & 2.4 & 0.0 \\
\hline & Depending on weather conditions & 0.0 & 0.0 & 0.0 & 14.8 & 4.6 & 20.0 & 7.1 & 32.1 \\
\hline \multirow{7}{*}{ When to spray } & After germination & 61.6 & 81.6 & 63.7 & 2.4 & 19.4 & 30.6 & 16.4 & 12.5 \\
\hline & After weeding & 13.2 & 13.2 & 5.5 & 42.9 & 25.5 & 41.7 & 36.4 & 46.9 \\
\hline & At flowering & 7.4 & 1.8 & 9.9 & 29.8 & 19.4 & 5.6 & 14.5 & 6.3 \\
\hline & After flowering & 5.8 & 0.9 & 13.2 & 19 & 20.4 & 2.8 & 7.3 & 3.1 \\
\hline & When it is humid & 1.6 & 0.0 & 6.6 & 1.2 & 4.1 & 0.0 & 0.0 & 3.1 \\
\hline & NA & 5.3 & 1.8 & 1.1 & 4.8 & 9.2 & 5.6 & 7.3 & 6.3 \\
\hline & When symptoms appear & 5.3 & 0.9 & 0.0 & 0.0 & 1.0 & 13.9 & 12.7 & 21.9 \\
\hline
\end{tabular}

Table 9. Desired attributes in new potato varieties (\% of respondents in each district).

\begin{tabular}{|c|c|c|c|c|c|c|c|c|}
\hline \multirow{2}{*}{$\begin{array}{l}\text { District } \\
\text { Attributes }\end{array}$} & & & \multirow[b]{2}{*}{ Kanungu } & \multirow[b]{2}{*}{ Rakai } & \multirow[b]{2}{*}{ Lwengo } & \multirow[b]{2}{*}{ Kween } & \multirow[b]{2}{*}{ Kapchorwa } & \multirow[b]{2}{*}{ Mbale } \\
\hline & Kabale & Kisoro & & & & & & \\
\hline High yielding & 84.8 & 87.5 & 95.7 & 73.0 & 76.5 & 93.3 & 78.6 & 89.3 \\
\hline Marketable & 53.1 & 38.4 & 35.7 & 28.6 & 39.7 & 43.3 & 54.8 & 0.0 \\
\hline Resistant to late blight & 28.1 & 16.1 & 42.9 & 50.8 & 52.9 & 46.7 & 31.0 & 57.1 \\
\hline Early maturing & 16.5 & 19.6 & 2.9 & 47.6 & 44.1 & 50.0 & 50.0 & 53.6 \\
\hline Good for eating & 15.9 & 4.5 & 0.0 & 6.4 & 0.0 & 16.7 & 0.0 & 3.6 \\
\hline Resistant to pests and diseases & 0.0 & 0.0 & 35.7 & 19.1 & 0.0 & 0.0 & 40.5 & 0.0 \\
\hline Resistant to bacterial wilt & 0.0 & 8.9 & 21.4 & 0.0 & 10.3 & 30.0 & 31.0 & 21.4 \\
\hline Red skinned & 40.8 & 4.5 & 0.0 & 0.0 & 0.0 & 0.0 & 0.0 & 14.3 \\
\hline Yellow flesh & 0.0 & 0.0 & 0.0 & 0.0 & 10.3 & 0.0 & 0.0 & 0.0 \\
\hline
\end{tabular}


used. Kanungu had the highest number of farmers sourcing fungicides from general traders (41\%). Mancozeb containing fungicides were generally being used by farmers possibly because they are relatively cheaper. However, farmers could not distinguish between contact and systemic fungicides most of the time. In some cases, farmers confused herbicides and growth boosters for fungicides in control and management of late blight.

Farmers sprayed against late blight several times in a season. Over $60 \%$ of the respondents sprayed more than three times in Rakai; $58.5 \%$ three times in Kanungu; $57.1 \%$ and $11.9 \%$ twice and once respectively in Kapchorwa (Table 8). On the spray intervals, $39.3 \%$ of the respondents sprayed weekly in Mbale; $57.1 \%$ biweekly in Kapchorwa; $34.3 \%$ after three weeks in Kanungu; and 20\% depended on the weather conditions. Farmers had different responses on when they decide to spray the potato crop against late blight. Some farmers followed crop growth stages while others sprayed on appearance of symptoms (19.0\%). On growth stages $77.5 \%$ of the respondents sprayed after germination in Kabale, Kanungu and Kisoro districts. Fifty percent of the farmers sprayed against LB after weeding in Kween, Kapchorwa and Mbale districts. On the other hand $33.6 \%$ of the farmers sprayed at flowering and $27.5 \%$ after flowering.

\section{Varietal attributes}

The results of this study identified high yield as the most preferred attribute across the three potato growing regions surveyed with over $70 \%$ of respondents (Table 9). Marketability, resistance to blight and early maturity followed. General resistance to pests and diseases was mentioned by farmers in Kanungu, Rakai and Kapchorwa districts. Farmers from all regions considered a variety good for eating while resistance to bacterial wilt was a major attribute for farmers in Eastern Uganda. Red skin was mentioned in Kabale, Kisoro and Mbale districts while yellow flesh was mentioned in Lwengo district (10.3\%).

\section{Discussion}

This study aimed at obtaining information on potato production in Uganda, major production constraints, current potato cultivars and preferences, plus farmers' knowledge on late blight disease and management. Individual farmers were interviewed to obtain the necessary information. The results of this study revealed potato as an important crop for both food and income security in Uganda. In addition to potato, farmers grow other crops for both food and household income. Major crops grown across all regions were beans and maize. Potato was generally grown in pure stands and occasionally mixed with other crops. Intercropping of potato with crops like maize, beans, banana and cassava was common in Central and Eastern regions, primarily as a measure to guard against crop failure. Variety mix was common in most fields in Eastern Uganda. This could be attributed to poor harvesting techniques where all potatoes are not picked up resulting in a large number of volunteers. In addition, improper storage could be a cause as small space is used for several varieties which end up being mixed. However, it could also be a way of minimizing the risk of crop failure (Sperling and Loevinsohn, 1993; Muthoni et al., 2013).

The overriding use of farm saved seed in Central Uganda (Table 3) can be attributed to absence of research stations and lack of training on the value of quality seed. On the other hand, the use of quality seed potato in other regions can be ascribed to their proximity to the research stations and NGOs working on potato. However, this percentage $(2 \%)$ is still low and it can be explained by the high cost of seed, bulkiness of potato seed and insufficient quantities produced by these research stations (Aheisibwe et al., 2015). In addition, farmers can keep their seed for two to three seasons without replacement (Muthoni et al., 2013). However, continual use of potato seed from informal sources promotes the spread of seed borne diseases mainly bacterial wilt (Kinyua et al., 2001) and viruses (Kakuhenzire et al., 2000).

Different potato varieties were grown across the three regions, but common to all were Rwangume and Victoria (Table 4). The wide adaptability of Victoria was mentioned by Ferris et al.(2001). The variety matures early although very susceptible to late blight. The spread of Rwangume to other parts of the country may be due to its red skin colour, good cooking quality, many tubers and relative tolerance to late blight. Also Rwangume generally has a high market demand. The absence of new and improved varieties in Central Uganda may be explained by the fact that most varieties are developed in the highlands, require cool temperatures and have a long maturity period. As a result, their productivity cannot be achieved in areas with short rain fall cycles and higher temperatures. Also efforts on potato research and farmer training have been centered in the highland areas .Therefore breeding efforts should be geared towards early maturing varieties with wide adaptability.

In general, there was a high turnover of varieties in South Western Uganda compared to other regions (Table 5). This could be explained by the fact that potato breeding and evaluation of candidate varieties takes place from this region. As a result farmers have easy access to new varieties and some obtain them from the on farm trials. Cruza was commonly abandoned in both Western and Eastern Uganda, while particular varieties were rejected in different districts. The abandonment of Cruza by most farmers could be attributed to its higher tendency to crumble when over cooked and being white skinned. This finding on Cruza is in agreement with what (Low, 1997) found out that it was the most likely variety to be abandoned by commercially conscience farmers in Bukinda (57\%) and Karengyere (44\%), Kabale district. The results of this study indicate that varieties which are white skinned are more easily abandoned than the red skinned ones. This is because they fetch lower market prices. As a result they are mainly grown for food security by most farmers as was the case for Kabera and Singo in Central Uganda.

Some farmers dropped Victoria because of its high susceptibility to diseases mainly late blight. Cruza on the other hand takes long to mature and becomes marshy on cooking. Most varieties were abandoned on account of low yields and poor marketability. This was also found in some areas of Kenya (Muthoni et al., 2013). Introduction of new and high yielding varieties also influenced the rejection of some varieties. This is in agreement with a study by Low (1997) who reported that in addition to ease of selling, four important reasons for varietal adoption were; high yield, good tuber size, late blight resistance and interest to try the new variety plus early maturity. There is therefore a need to develop high yielding varieties with end user traits. Early maturity is a key trait in variety development especially in the face of changing climate and shift of potato cultivation from the traditional highlands to mid and low lands.

Diseases were the most important production constraint (Table 6). Over 35\% of the farmers mentioned both bacterial wilt and late blight as major diseases affecting potato production and these were followed by viruses. These results 
are similar to those of other scholars (Kaguongo et al., 2010; Muhinyuza et al., 2012; Muthoni et al., 2013) who found diseases to be the most limiting factor in potato production in Rwanda and Kenya. Farmers in the present study rated bacterial wilt higher than late blight. The same results were found by Ortiz et al (1997) in a study to understand farmers' responses to late blight. This may be because bacterial wilt (BW) is both seed and soil borne, with no efficient chemical control available and its effect is escalated by the use of seed from informal sources (Kinyua et al., 2001). As much as late blight is a devastating disease of potato, in most surveyed districts, farmers say it can be managed by spraying using fungicides. However, this has a big bearing on the cost of production (Forbes, 2012). Therefore, the use of resistant varieties is paramount if potato production is to be sustainable. Conversely, farmers in this study never mentioned the use of resistant varieties to control late blight. This may be due to the fact that such varieties are not presently available.

Declining soil fertility was typically mentioned in the highland areas (Table 6). This may be attributed to the high rate of soil erosion, poor soil fertility management practices and over cultivation due to small land holdings coupled with a high population density (Low, 1997; Lemaga et al., 2001; Muthoni et al., 2013). Low market price at the harvest time was particularly mentioned by farmers in Central and Eastern Uganda. This may be due to limited or no storage facilities and as a result potatoes are sold at the prevailing market prices.

Failure of farmers to recognize late blight, spread of the disease and its symptoms was also observed by Ortiz et al. (1997) in a study to understand farmers' responses to late blight. This calls for the need of farmer education and training on potato production and disease management. Over $20 \%$ of the respondents in the districts of Kanungu and Rakai said the disease is severe in both seasons. Heavy rainfall was especially mentioned as the most enhancing condition for the spread of late blight in all the districts, which is in agreement with the findings of Ortiz et al. (1997). The low number of farmers who had knowledge on the spread of late blight could be attributed to lack of training on the spread and management of the disease. The majority of farmers who did a blanket fungicide application would save on production costs if they waited for the onset of the disease and constantly monitored the crop (Kakuhenzire et al., 2007). The results of this study identified high yield (over $70 \%$ respondents) as the most preferred attribute across the three potato growing regions (Table 9). These findings are similar to those from previous studies by Low (1997) and Muhinyuza et al. (2012) who found high yields, marketability, resistance to diseases and early maturity as the most desirable attributes in new cultivars and for variety adoption.

\section{Materials and methods}

\section{Study sites}

A survey was carried out in three major potato growing regions in Uganda namely, Central, Eastern Highlands (Mount Elgon) and South Western Highlands (Kigezi region) from May to September 2015. All regions are suitable for potato production with a bimodal rainfall pattern of short rains (from March to May) and the long rains (from August to December). However, in the South Western highlands; potato growing is almost done throughout the year (Low, 1997; Ferris et al., 2001) at altitudes ranging from 1200-2500 m. The traditional production zones of Kigezi and Mount Elgon are favourable for potato production due to their deep volcanic soils, high altitudes with mild temperatures (10 $\left.30^{\circ} \mathrm{C}\right)$, and abundant rainfall $(900-1400 \mathrm{~mm})$.

Sampling was done at different administrative levels from district, sub-county to villages. In each of these regions major potato producing districts were chosen as follows: Rakai and Lwengo in Central Uganda; Kween, Kapchorwa and Mbale in Eastern Uganda; and Kabale, Kanungu and Kisoro from South Western Uganda. Sub-counties where potato is the main crop were identified with the help of the district production staff and sub-county chiefs. Individual farmers were approached with the guidance of village chairpersons. In all these areas, potato is a major food and cash crop.

\section{Data collection and analysis}

Primary data was collected using a semi-structured questionnaire that was administered to individual farmers. The questionnaire constituted open ended questions to allow full expression so as to obtain as much information from farmers as possible. A pretesting was done on fifteen farmers in Eastern Uganda, changes were effected and the formal survey started. The survey team consisted of a breeder, research assistant, an agriculture extension officer and three enumerators from each district. Only households with potato fields were sampled and interviews were carried out in the field to ascertain the varieties grown, incidence of late blight and management practices. The interviews were conducted in local languages and in some areas such as Eastern Uganda, interpreters were used.

Data was collected on farm characteristics and location using a global positioning system (GPS-Garmin Inc. Kansas, USA), where latitudes, longitudes and altitudes were recorded. Farmers listed major crops on their farms, potato varieties currently grown and those abandoned. Additionally, data was collected on source of seed, production constraints, desired attributes, and knowledge of late blight symptoms and management options. The data was analysed using SPSS software (SPSS, 2010) and Microsoft excel. Data analysis was descriptive (percentages and means).

\section{Conclusion}

This PRA study has resulted in understanding of potato production in Uganda. Potato is grown for both food and income; and largely by small scale farmers. In addition to potato, farmers grow other crops for household income and food security. Farmers grow different potato varieties and seed used for subsequent seasons is mainly farm saved. Varieties grown differ from one area to another and so are those abandoned. Potato growing is constrained by many factors but diseases are the most limiting and late blight is the most devastating disease. Farmers manage late blight by mainly spraying using fungicides. However, this is not sustainable for the environment and the cost is not as affordable by the majority of the small scale farmers. This therefore creates the need to breed for host resistance. The results of this study indicate that farmers learn best from each other. For example farmers in a given location tended to use the same fungicides, variety and rotation patterns meaning that they share knowledge with each other. This should be used as a means of technology transfer and adoption. 
The Alliance for a Green Revolution in Africa (AGRA) is sincerely thanked for funding this study. Due thanks to the National Agricultural Research Organisation (NARO) for all the support and farmers who willingly provided information.

\section{References}

Aheisibwe AR, Barekye A, Namugga P, Byarugaba A (2015) Challenges and opportunities for quality seed potato availability and production in Uganda. Uganda J Agri Sci. 16: $149-159$.

FAOSTAT (2014) Production statistics. Available at http://faostat.fao.org., (accessed 11 July 2016).

Ferris GO, Crissman C, Ewell P, Lemaga B (2001) Uganda's Irish Potato Sector. pp: 6-37.

Forbes G (2012) Using host resistance to manage potato late blight with particular reference to developing countries. Potato Res. 55: 205-216.

Garrett K, Nelson R, Mundt C, Chacon G, Jaramillo R, Forbes G (2001) The effects of host diversity and other management components on epidemics of potato late blight in the humid highland tropics. Phytopathology. 91: 9931000.

Hassanpanah D, Gurbanov E, Gadimov A, Shahriari R (2008) Determination of yield stability in advanced potato cultivars as affected by water deficit and potassium humate in Ardabil region, Iran. Pak J Biol Sci. 11: 1354-1359.

Hijmans RJ (2001) Global distribution of the potato crop. Potato Research 78: 403-412.

Joshi A, Witcombe JR (1996) Farmer participatory crop improvement. II. Participatory varietal selection, a case study in India. Exp Agr. 32: 461-477.

Kaguongo W, Ng'ang'a N, Muthoka N, Muthami F, Maingi G (2010) Seed potato subsector master plan for Kenya (2009-2014). Seed potato study sponsored by GTZ-PSDA, USAID, CIP and Government of Kenya. Ministry of Agriculture, Kenya.

Kakuhenzire R, Hakiza JJ, Mateeka B, Lemaga B, Salazar L, Olanya, M (2000) Incidence and importance of potato viruses in south-western Uganda. African Potato Association Conference Proceedings. 5: 285-290.

Kakuhenzire R, Kimoone G, Wagoire WW, Gildemacher P, Lemaga B, Adipala E, Mateeka B (2007) Adapting fungicide spraying regimes to potato late blight host resistance in Uganda. African Crop Science Conference Proceedings. 8: 801-807).

Kinyua Z, Smith J, Lung'aho C, Olanya M, Priou S (2001) On-farm successes and challenges of producing bacterial wilt-free tubers in seed plots in Kenya. ACJS 9: 279-285.

Lemaga B (2001) Integrated control of potato bacterial wilt in Kabale district, South Western

Uganda. In Scientist and Farmer. Partners in Research for the 21st Century, Program Report. 1999-2000. pp. 129-141.

Low J (1997) Potato in southwest Uganda: threats to sustainable production. Afr Crop Sci J. 5: 395-412.

Muhinyuza JB, Shimelis H, Melis R, Sibiya J, Nzaramba MN (2012) Participatory assessment of potato production constraints and trait preferences in potato cultivar development in Rwanda. Int J Develop Sust. 1: 358-380.

Muthoni J, Shimelis H, Melis R (2013) Potato production in Kenya: Farming systems and production constraints. Can J Agr Sci. 5: 182-197.
Ortiz O, Winters P, Fano H, Thiele G, Guaman S, Torrez R (1997) Understanding farmers' responses to late blight: evidence from Peru, Bolivia, Ecuador, and Uganda. Program Report 1998: 101-109.

Sedláková V, Dejmalová J, Hausvater E, Sedlák P, Doležal P, Mazáková J (2011) Effect of Phytophthora infestans on potato yield in dependence on variety characteristics and fungicide control. Plant Soil Environ. 57: 486-491.

Sperling L, Loevinsohn ME (1993) The dynamics of adoption: distribution and mortality of bean varieties among small farmers in Rwanda. Agr Syst. 41: 441-453.

SPSS.(2010) Statistical Package for Social Scientists. SPSS for Windows Release 19.0.0. Chicago, IL, www.spss.com.

Witcombe JR, Joshi KD, Gyawali S, Musa AM, Johansen C, Virk DS, Sthapit BR (2005) Participatory plant breeding is better described as highly client-oriented plant breeding. I. Four indicators of client -orientation in plant breeding. Exp Agr. 41, 299-319.

Witcombe JR (2009) Methodologies for generating variability. Part 3: The development of base populations and their improvement by reccurrent", in Ceccarelli et al. (Ed.), Plant breeding and farmer participation. Food and Agriculture Organization, Rome. pp. 139-157 